\title{
FISCAL DECENTRALIZATION: THE PRACTICE OF INTERACTION BETWEEN CENTRAL AND LOCAL AUTHORITIES IN UKRAINE AND WORLD
}

\begin{abstract}
In the course of assigning expenditure and revenue powers to local self-government, it is necessary to clearly define and distinguish between the functions of the state and local authorities, to take into account the real needs of newly-created hromadas, to use management technologies based on the foundations of "new public management", and to prioritize the interests of citizens in order to make managerial decisions relevant exactly to the local level. In turn, the development of public relations dictates the urgent necessity to search for new ideas on governance in modern states, to search for new technologies, new tactics and strategies for regulating fiscal decentralization progress, to apply management technologies based on the "new public management", and to prioritize the interests of citizens in order to make managerial decisions relevant exactly to the local level. The current conditions of local self-government institution and the form of its interaction with the state authorities along with transformation of Ukrainian society and implementation of fiscal decentralization policy require in-depth analysis and are of interest for current research. Briefly, the key areas of strengthening the financial independence of local self-government are identified, via a clear definition of the central and local executive bodies structure and powers, strengthening the role of local, implementing the reserves on own revenue base, accounting the financial policies and forms of fiscal support to local selfgovernments, introducing the new approaches to the budget process - "new public management".
\end{abstract}

Key words: fiscal decentralization, expenditure decentralization, expenditures, spending power, local selfgovernment.

JEL Classification: H20 H30 H41 H50H72 H77 O23.

Anna KOVALCHUK, Postgraduate Student School of Economics

Shandong University, PRC

kgb_a@ukr.net

https://orcid.org/0000-0002-1487-4572

\section{Introduction}

Ensuring the financial independence of hromadas by strengthening the revenue base of local budgets is one of the most important areas on improving not only the public finance management system in Ukrainian economy, but also improving the institutional system of interaction between public authorities in the process of implementing financial powers. The scope occupies a special place in the system of determinants on "new public management", development strategy on local finances, and becomes the significant counterpoint of official and program based documents embodying fiscal decentralization in Ukraine (Verkhovna Rada of Ukraine, 1997; Verkhovna Rada of Ukraine, 1999; Verkhovna Rada of Ukraine, 2010; Verkhovna Rada of Ukraine, 2014; Verkhovna Rada of Ukraine, 2015).

\section{Analysis of recent research and publications}

Now, researchers note Ukraine still to possess centralized model of local budgeting, which is devoid of financial autonomy, which own revenues are shaped by intergovernmental transfers and revenue ratios. Theoretical and practical aspects as to shaping local budgets in the conditions of decentralization on fiscal powers were investigated by Ukrainian researchers, areas of interest are as follows:

- issues on decentralization of local budgets (Pohorielov, 2018; Arabchuk, 2016; Bykadorova, 2010; Kovalevych, 2014);

- prospects and effectiveness of local budgeting (Furdychko, 2015; Volokhova, 2014; Bucovetsky, Smart, 2006; Piven', 2012);

- administrative aspect of reforming local self-government institutions (Kravtsiv, 2016; Lunina, 2006); 
- structural, methodological, tax aspects (Mel'nik, 2013; Panasiuk, 2015; Shults, 2016; Yashina, Ryabov, 2015);

- planning of local finances (Kyrylenko et al., 2015).

Determining the impact of fiscal decentralization on the socio-economic development of the regions is presented in the research works of eminent foreign scholars on the theory of fiscal decentralization (Chua, 1995; Tiebout, 1956; Easson, Zolt, 2002; Martinez-Vazguez, Boex, 1999; Samimi et al., 2010; Shadbegian, 1999; Schneider, 2003).

\section{The purpose of the article}

The current conditions of local self-government institution and the form of its interaction with the state authorities along with transformation of Ukrainian society and implementation of fiscal decentralization policy require in-depth analysis and are of interest for current research.

\section{Main statements}

Despite the legislative consolidation of the new concept of local self-government and the five-year practice of functioning of local self-government shaped by hromadas and local authorities in Ukraine within this concept, it is premature to regard the local self-government institutionalization process as an arranged one, to assume local public authorities to be independent, and the civil society with its infrastructure to be completed to the full. To highlight, the key objective of fiscal decentralization, still, is to strengthen the financial foundations of local self-government, to improve the institutional system of interaction between public authorities and local self-government bodies, especially in the context of spending powers. Implementation of the concept of financial support of local self-government in (Verkhovna Rada of Ukraine, 1997; Verkhovna Rada of Ukraine, 1999; Verkhovna Rada of Ukraine, 2010; Verkhovna Rada of Ukraine, 2014; Verkhovna Rada of Ukraine, 2015) was to ensure the strengthening and balance of local budgets through the redistribution of revenue and expenditure powers on different public authority levels and the application of new methodological approaches to budgeting.

These approaches include, in particular: redistribution of an expansive definition of local budgets own revenues; the transition to set up medium-term financial planning at the local level (Lunina, 2006; Pohorielov, 2018); the introduction of results-oriented budget planning methods and improving the efficiency of local budget expenditures. The fruits of financial decentralization and subsequent reform of the budget process in Ukraine resulted in a number of changes those possess an ambiguous impact on local authorities (Larina, 2013; Serebrianska, 2015), so that the ambiguities in the territorial organization of local self-government were eliminated, the competences of local government institutions were defined, the revenue powers and expenditures of local self-government bodies were delimited.

Within the main trends in Ukraine, the movement has started:

- to ensure the compliance as to revenue authority and expenditure commitments of local budgets;

- to balance local budgets by means of securing permanent income sources;

- to elaborate the mechanisms to eliminate and to prevent the emergence of unfunded expenses;

- as well as to elaborate the mechanisms to finance the public powers shifted on local level;

- to formalize the procedures for providing financial assistance to hromadas from the local and central budgets.

At the same time, strengthening the financial autonomy of hromadas remains an urgent task.

So far, regarding the Central and Eastern Europe countries with transitive economies, the process of fiscal decentralization also reveals many problems and contradictions. The main objective there is to resume economic growth, while preserving the entire system of social guarantees in the provision of public goods (De Sil'va, Kurlyandskaya, 2006). Thus, carrying out the budget decentralization in the former socialist countries was marked by some progress, but the degree of decentralization varies significantly depending on the level of development of public systems, the fairness of the redistribution of financial resources, the quality of the dialogue between the central government and local authorities, and the strength of the political, economic and financial situation of the territorial formations. To continue, researchers also highlight the "image-building" point: the new democratic governments aimed at getting rid of the phenomena associated with the communist past, one of which was extremely centralized governance (Rodrígues-Pose, Krøijer, 2009).

That is the experience of many developing countries with transitive economies (India, Argentina, Brazil etc.), local authorities were unable to adequately solve the tasks shifted down, which was caused by various reasons (mainly due to the lack of necessary institutional conditions) and generally led to the 
discrediting of decentralized government (Larina, 2013; De Sil'va, Kurlyandskaya, 2006; Shah, 2006). In turn, effectiveness of decentralization is demonstrated by the federal states with a high degree of budget decentralization and stable macroeconomic indicators (Germany). According to experts (Larina, 2013; Shakh, 2010; Lunina, 2010; Martinez-Vazguez, Boex, 1999; Samimi et al., 2010; Shults, 2016; Shah, 2006; Tiebout, 1956; Volokhova, 2014), those states are increasingly approaching the balance of "centralization - decentralization". These achievements are based, first of all, on the politically correct, socially and economically justified rules and mechanisms for coordinated distribution of powers and resources at the levels of administration.

For instance, fiscal decentralization in Germany was initiated by the report of the German Association of Municipalities (Gemeindeverband) on updating local governance, where the following were underlined as the main ideas of the reform:

1) the concept of "product" (all the results of the authorities' activities and the services provided are described by the term "product"). In Ukraine, this concept is closely related to the issue of the term "guaranteed services" (Item 1 of article 86 of the Budget Code of Ukraine). Up to now, the Budget Code of Ukraine does not clearly define the concept of "guaranteed services". That is, an important factor that negatively affects the performance and financing of the functions of central and local authorities, and is inconsistent with the legislative norms (Verkhovna Rada of Ukraine, 2010; Verkhovna Rada of Ukraine, 1997; Bykadorova, 2010);

2) the creation of quasi-autonomous units being responsible for specific services and the resources needed to provide the services mentioned;

3 ) the result-oriented budgeting and reporting system based on stated performance indicators. To note, one of the main advantages of the German municipal finance system is its independent distribution of tax revenues, local budget revenues in industrialized countries, on average, can be structured as follows, $50 \%$ of local income is generated from taxes, $20 \%$ - consumer fees, and 30\% - transfers from the upper power authorities (Shah, 2006; Shakh, 2010: 63).

Benefiting over this principle, local authorities receive a stable income and are not dependent on a local business tax or on a commercial tax. Moreover, the distribution of tax revenues has an advantage over vertical subsidies, since central authorities mainly use subsidies to motivate or punish local authorities.

Since 1990-s, Ukraine also has a policy of equalizing the financial condition of the regions, which sharply polarizes in terms of income. Anyway, in the Ukrainian version, the system still does not show high performance results. In conditions of exceptionally uneven economic development of the territory, support for economically inefficient regions was carried out first through tax incentives, which led to the formation of "gaps" in the state budget, then through subsidies and subventions".

Currently, the opinion on the necessity to switch to a policy of financial support for financially weak regions due to financially strong regions is giving way to competition among regions for obtaining support by independently attracting investment and business. This will allow to gradually replace budget allocations with own revenue sources, stimulating local authorities to open new enterprises, create jobs and to advance the infrastructure.

However, the denial of the ability of local administrations to pursue an effective budget policy is based on arguments, as follows: the development of tax autonomy at the local level can lead to increased territorial imbalance even in the case of an optimally shaped system of differentiating costs and incomes due to levels of government. Nowadays, the state level represents the state budget, at the local levels oblast budgets, budgets of cities of regional/oblast importance, budgets of the hromadas, rayon/district budgets, as well as rural, settlement budgets and budgets of cities of rayon importance. To go on, in Ukraine, citizens often are employed in enterprises and establishments located outside the recently residing territorial community. This kind of situation is quite widespread, in turn, one of the major budget-forming taxes (income tax) is credited to the local budget where the legal entity in which the payee is employed or located. And the community in which the income tax payer resides finances the services he consumes but has no additional tax revenue. There is an imbalance at the local budget level: taxes are paid in one community and services are provided in another one.

Accordingly, it would be advisable to form an income tax fund with its subsequent redistribution, which takes into account the number of registered enterprises-tax agents, the number of officially registered employees, and the total population of the respective territory. In accordance with direct approach of public services to the final consumer (Verkhovna Rada of Ukraine, 2010) and for the sake of provision the public benefits that have scale and external effects, those public services (guaranteed services) is 
better to attribute to local authority, later to the oblast level, in particular, such public services as: local fire protection, medical services of hospitals of general purpose, garbage disposal services, the provision of those are provided to the population of several villages, settlements within, even, different territorial communities or hromadas (Verkhovna Rada of Ukraine, 2010; Serebrianska, 2015). It is also advisable to keep with these powers of rayon councils for the period of uniting of hromadas, as follows: the power to provide the public services to the villages, cities and settlements of various self-government units or within different hromadas, medical services covered by public hospitals of general medicine, maternity hospitals, protection of social welfare, fire protection, waste disposal, construction, reconstruction, repair and maintenance of public highways.

The main risks to fail the fiscal decentralization in terms of effective public interaction and delegation of powers are:

1) the initial limited financial competence of local authorities, their tendency to finance day-to-day consumption (rather than increase investment costs), and low administrative capacities that do not allow the efficient use of local tax potential and provide local public goods, taking into account the needs of the population;

2) the system of inter-budget transfers, which is being formed as a "counterbalance" to territorial imbalances, can have a negative impact, as growing transfers generate dependence of the local budget policy and, in fact, are a compensation for ineffective actions of local administrations;

3 ) inefficient management of the local budget due to the lack of professionals, properly shaped and trained stuff and/or low qualification of local officials to perform new functions, to specify: a) lack of strategic planning, including the formulated strategy and timetable for its implementation; b) lack of qualified specialists; c) lack of time to accomplish the set goals in the presence of high expectations about the results of fiscal reforms;

4) corruption risks, which somehow correspond to a previous statement, increasing, the possibility to merger the state and business at the local level, since a large part of local deputies are representatives of the same business, arose opportunities for bribes, ways to corrupt of public funds;

5 ) the issue of distribution the powers between local self-government and executive authorities in general, as well as the functions and powers between local councils (rayon/oblast rada) of united territorial communities (hromadas) and rayon state administrations and rayon radas are not settled yet;

6) as the very climax of all above mentioned, that flows and directly reveals both the society preparedness for reforms and the work done by state and local authorities in order to prepare the society for above mentioned reforms. So in terms of the ordinary inhabitants, the stereotypes and misunderstandings accompany with the fiscal decentralization are still retained. It all leads to the lack of support for the decentralization in hromadas emerging, as well as to resistance from local administrations and local councils (radas), local authorities, civil society institutions and civic organizations.

In general, the experience of the other countries shows (Shakh, 2010; Shah, 2006; Rodrígues-Pose, Krøijer, 2009; Samimi et al., 2010; De Sil'va, Kurlyandskaya, 2006) that the reform of the budget process on a new conceptual basis is a multi-stage, iterative, long-lasting process being slightly opposed by locals, along it is notable to inevitably change and improve specific methods of managing revenues and expenses. So that, in those countries, to name Germany, where the principles of budgeting by results are being consistently implemented, authorities and the public find the positive effect of fiscal decentralization initiation. At the same time, the effectiveness of the decentralization tools itself is rather difficult to quantify in modern conditions.

\section{Conclusions}

In order to summarize the above noted issues, the following key areas of strengthening the financial independence of local self-government can be identified, first of all, via a clear definition of the central and local executive bodies structure and powers, and:

1) strengthening the role of local taxes in the formation of the revenue side of local budgets, as well as securing to local authorities the additional taxes or deductions and "guaranteed services";

2) to find and to implement the reserves for the formation by local self-governments own revenue base, creating a system of incentives to pursue an active policy to build up own tax and non-tax sources of income, improving the efficiency of budget expenditures by moving to program structure, and improving local finance management; 
3) to promptly account the implementation of financial policies and the choice of forms of fiscal support to local self-governments to accumulate own fiscal potential and to lift the self-effectiveness, to stimulate the result-oriented budgeting and reporting system based on stated performance indicators;

4) to introduce to the general public new approaches to the budget process, according to the concept of a "new public management", in order to prevent social resistance to fiscal decentralization implementation.

\section{References:}

1. Verkhovna Rada of Ukraine (2010). Biudzhetnyi kodeks Ukrainy: Zakon Ukrainy vid 8 lypnia 2010 r. № 2456-VI [Budget Code of Ukraine: Law of Ukraine of July 8, 2010 № 2456-VI]. Retrieved from: https://zakon.rada.gov.ua/laws/show/2456-17 (accessed: 10.03.2020) [in Ukrainian].

2. Verkhovna Rada of Ukraine (2014). Pro vnesennia zmin do Podatkovoho kodeksu Ukrainy ta deiakykh zakonodavchykh aktiv Ukrainy shchodo podatkovoi reformy: Zakon Ukrainy vid 28 hrudnia 2014 r. № 71-VIII [On amendments to the Tax Code of Ukraine and certain legislative acts of Ukraine concerning tax reform: Law of Ukraine of December 28, 2014 № 71-VIII]. Retrieved from: https://zakon.rada.gov.ua/laws/show/ 71-19\#Text (accessed: 10.03.2020) [in Ukrainian].

3. Verkhovna Rada of Ukraine (1997). Pro mistseve samovriaduvannia v Ukraini: Zakon Ukrainy vid 21 travnia 1997 r. № 280/97-BP [On local self-government in Ukraine: Law of Ukraine of May 21, 1997 № 280/97-BP]. Retrieved from: https://zakon.rada.gov.ua/laws/show/280/97-вp (accessed: 05.03.2020) [in Ukrainian].

4. Verkhovna Rada of Ukraine (1999). Pro mistsevi derzhavni administratsii: Zakon Ukrainy vid 9 kvitnia 1999 r. № 586-XIV [On local state administrations: Law of Ukraine of April 9, 1999 № 586-XIV]. Retrieved from: http://zakon3.rada.gov.ua/laws/show/586-14 (accessed: 20.03.2020) [in Ukrainian].

5. Verkhovna Rada of Ukraine (2015). Pro dobrovilne obiednannia terytorialnykh hromad: Zakon Ukrainy vid 5 liutoho 2015 r. № 157-VIII [On voluntary association of territorial communities: Law of Ukraine of February 5, 2015 № 157-VIII]. Retrieved from: https://zakon.rada.gov.ua/laws/show/157-19 (accessed: 20.03.2020) [in Ukrainian].

6. Arabchuk, Ya.I. (2016). Finansova detsentralizatsiia - osnovna skladova spromozhnoi hromady [Financial decentralization is a key component of a prosperous community]. Teoriia ta praktyka derzhavnoho upravlinnia i mistsevoho samovriaduvannia, no. 1. Retrieved from: http://el-zbirn-du.at.ua/2016_1/18.pdf (accessed: 21.02.2020) [in Ukrainian].

7. Bykadorova, N.O. (2010). Finansova detsentralizatsiia mistsevoho samovriaduvannia [Financial decentralization of local self-government]. Ekonomichnyi visnyk Donbasu, no. 2(20), pp. 145-151 [in Ukrainian].

8. Bucovetsky, S., Smart, M. (2006). The Efficiency Consequences of Local Revenue Equalization: Tax Competition and Tax Distortions. Journal of public economic theory, vol. 8, iss. 1, pp. 119-144 [in English].

9. Chua, D. (1995). Tax Incentives. Tax Policy Handbook / P. Shome (ed.). Washington, DC: International Monetary Fund, pp. 165-168 [in English].

10. Easson, A., Zolt, E. (2002). Tax Incentives. Washington, DC: World Bank Institute. Retrieved from: http://siteresources.worldbank.org/INTTPA/Resources/EassonZoltPaper.pdf (accessed: 20.02.2020) [in English].

11. Furdychko, L.Ye. (2015). Detsentralizatsiia: finansova nezalezhnist mistsevykh biudzhetiv Ukrainy [Decentralization: financial independence of local budgets of Ukraine]. Sotsialno-ekonomichni problemy suchasnoho periodu Ukrainy, iss. 5, pp. 39-42 [in Ukrainian].

12. Kyrylenko, O.P., Malyniak, B.S., Pysmennyi, V.V., Rusin, V.M. (2015). Planuvannia ta upravlinnia finansovymy resursamy terytorialnoi hromady: navchalnyi posibnyk [Planning and management of financial resources of the territorial community: textbook]. Kyiv: VI EN EI, 396 p. [in Ukrainian].

13. Kovalevych, D.A. (2014). Mistsevi biudzhety ta yikh rol u terytorialnomu rozvytku [Local budgets and their role in territorial development]. Visnyk Chernivetskoho torhovelno-ekonomichnoho instytutu. Seriia "Ekonomichni nauky", iss. 2(54), pp. 198-203 [in Ukrainian].

14. Kravtsiv, V.S. (ed.) (2016). Administratyvno-terytorialnyi ustrii Ukrainy: metodolohichni osnovy ta praktyka reformuvannia: monohrafiia [Administrative-territorial structure of Ukraine: methodological bases and practice of reforming: monograph]. Lviv: Institute of Regional Research named after M.I. Dolishniy of the NAS of Ukraine, 264 p. [in Ukrainian].

15. Larina, S.E. (2013). Obshchee i osobennoe v razvitii byudzhetnoy detsentralizatsii [General and special in the development of budget decentralization]. Vestnik Adygeyskogo gosudarstvennogo universiteta. Seriya 5 "Ekonomika", iss. 4(131), pp. 43-52. Retrieved from: https://cyberleninka.ru/article/n/obschee-i-osobennoev-razvitii-byudzhetnoy-detsentralizatsii (accessed: 08.03.2020) [in Russian]. 
16. Shakh, A. (ed.) (2010). Upravlenie na mestnom urovne $\mathrm{v}$ industrial'no razvitykh stranakh [Local government in industrialized countries], transl. from English. Moscow: Ves' Mir, 416 p. Retrieved from: http://documents.worldbank.org/curated/en/905331468333261837/pdf/368090PUB0RUSS0100countries0 Russian.pdf (accessed: 27.03.2020) [in Russian].

17. Lunina, I.O. (2006). Formuvannia mistsevykh biudzhetiv u konteksti zavdan administratyvnoterytorialnoi reform [Formation of local budgets in the context of tasks of administrative-territorial reform]. Ekonomika Ukrainy, no. 1, pp. 22-31 [in Ukrainian].

18. Martinez-Vazguez, J., Boex, J. (1999). The design of equalization grants: theory and applications. Retrieved from: https://www.researchgate.net/publication/265142703_The_design_of_equalization_grants_ Theory_and_applications (accessed: 20.02.2020) [in English].

19. Mel'nik, E.N. (2013). Osnovnye podkhody $\mathrm{k}$ issledovaniyu nalogov $\mathrm{v}$ teoriyakh ekonomicheskogo rosta i razvitiya gosudarstva i regionov [The main approaches to the study of taxes in theories of economic growth and development of the state and regions]. Vestnik Voronezhskogo gosudarstvennogo universiteta. Seriya "Ekonomika i upravlenie", no. 1, pp. 21-29 [in Russian].

20. Panasiuk, O.Yu. (2015). Otsinka finansovoi stiikosti mistsevykh biudzhetiv v zabezpechenni sotsialnoekonomichnoho rozvytku silskykh terytorii [Assessment of the financial stability of local budgets in ensuring the socio-economic development of rural areas]. Efektyvna ekonomika, no. 11. Retrieved from: http://nbuv. gov.ua/UJRN/efek_2015 11 95 (accessed: 03.03.2020) [in Ukrainian].

21. Piven', I.G. (2012). Metodika otsenki effektivnosti sistemy strategicheskogo upravleniya sotsial'noekonomicheskim razvitiem regiona [Methodology for assessing the effectiveness of the strategic management system of the socio-economic development of the region]. Teoriya i praktika obshchestvennogo razvitiya, no. 3, pp. 333-338. Retrieved from: http://teoriapractica.ru/rus/files/arhiv_zhurnala/2012/3/ekonomika/piven.pdf (accessed: 15.02.2020) [in Russian].

22. Pohorielov, V.S. (2018). Vplyv fiskalnoi detsentralizatsii na mistsevi biudzhety v Ukraini [The impact of fiscal decentralization on local budgets in Ukraine]. Naukovyi visnyk Uzhhorodskoho natsionalnoho universytetu. Seriia "Mizhnarodni ekonomichni vidnosyny ta svitove hospodarstvo", iss. 19(2), pp. 141-144 [in Ukrainian].

23. Rodrígues-Pose, A., Krøijer, A. (2009). Fiscal Decentralization and Economic Growth in Central and Eastern Europe. Growth and Change, vol. 40, no. 3, pp. 387-417 [in English].

24. Samimi, A.J., Petanlar, S.K., Haddad, G.K., Alizadeh, M. (2010). Fiscal Decentralization and Economic Growth: A Nonlinear Model for Provinces of Iran. Iranian Economic Review, vol. 15(26), pp. 125-133 [in English].

25. Schneider, A. (2003). Decentralization: conceptualization and measurement. Studies in Comparative International Development, vol. 38(3), pp. 32-56 [in English].

26. Shults, S.L. (ed.) (2016). Rehionalna strukturna polityka: suchasni tendentsii ta novi vyklyky: monohrafiia [Regional structural policy: current trends and new challenges: monograph]. Lviv: Institute of Regional Research named after M.I. Dolishniy of the NAS of Ukraine, 328 p. Retrieved from: http://ird.gov.ua/ irdp/p20160103.pdf (accessed: 01.02.2020) [in Ukrainian].

27. Serebrianska, D.M. (2015). Rozpodil vydatkiv mizh rivniamy mistsevykh biudzhetiv v umovakh biudzhetnoi detsentralizatsii [Distribution of expenditures between levels of local budgets in terms of budget decentralization] (Extended abstract of candidate's thesis). Kyiv: Institute of Economics and Forecasting of the National Academy of Sciences of Ukraine, 24 p. [in Ukrainian].

28. Shadbegian, R. (1999). The Effect of Tax and Expenditure Limitations on the Revenue Structure of Local Government, 1962-87. National Tax Journal, vol. 52, no. 2, pp. 221-237. Retrieved from: https://www.jstor.org/stable/pdf/41789391.pdf?seq=1 (accessed: 21.03.2020) [in English].

29. De Sil'va, M., Kurlyandskaya, G. (eds.) (2006). Razvitie byudzhetnogo federalizma: mezhdunarodnyy opyt i rossiyskaya praktika [The development of fiscal federalism: international experience and Russian practice], transl. from English. Moscow: Ves' Mir, 464 p. [in Russian].

30. Shah, A. (ed.) (2006). Local governance in developing countries. Washington, D.C.: World Bank, 457 p. [in English].

31. Tiebout, Ch.M. (1956). A Pure Theory of Local Expenditures. Journal of Political Economy, vol. 64, no. 3, pp. 416-424 [in English].

32. Volokhova, I.S. (2014). Mistsevi finansy ta perspektyvy pohlyblennia finansovoi detsentralizatsii v Ukraini: monohrafia [Local finances and prospects for deepening financial decentralization in Ukraine: monograph]. Odesa: Atlant, 462 p. [in Ukrainian].

33. Yashina, N.I, Ryabov, A.A. (2015). Metodologicheskie aspekty opredeleniya nalogovoy nagruzki s uchetom byudzhetoobrazuyushchikh pokazateley [Methodological aspects of determining the tax burden, taking into account budget-forming indicators]. Izvestiya Ural'skogo gosudarstvennogo ekonomicheskogo universiteta, no. 3(59), pp. 30-38 [in Russian]. 


\title{
ФІНАНСОВА ДЕЦЕНТРАЛІЗАЦІЯ: ПРАКТИКА ВЗАЕМОДІЇ ОРГАНІВ ДЕРЖАВНОЇ ВЛАДИ Й ОРГАНІВ МІСЦЕВОГО САМОВРЯДУВАННЯ В УКРАЇНI ТА СВІТІ
}

\author{
Анна КОВАЛЬЧУК, \\ аспірант Школи економіки \\ Шаньдунського університету, КНР \\ kgba@ukr.net \\ https://orcid.org/0000-0002-1487-4572
}

У прочесі реалізащії повноважень зі встановлення й реалізащії видатків і доходів у процесі фінансової децентралізаиії необхідно чітко розрізняти функиії державних та місиевих органів влади, враховувати в роботі реальні потреби новоутворених громад, використовувати управлінські технології, залишати пріоритетними інтереси саме громадян, а також розробляти та приймати управлінські рішення, значимі для місцевого рівня. У роботі використані такі методи дослідження, як аналіз і синтез, порівняння та узагальнення. Сучасний стан $i$ перспективи розвитку інституту місиевого самоврядування та форми його взаємодії з органами держсавної влади разом із трансформацією українського суспільства й реалізачією політики фінансової дещентралізаиї потребують глибокого аналізу та становлять інтерес для ивого дослідження. У статті визначено ключові напрями посилення фінансової незалежності місиевого самоврядування такими шляхами: чіткого визначення структури й повноважень центральних і місиевих органів виконавчої влади; посилення ролі місиевих органів влади; упровадження резервів щодо створення власної дохідної бази, форм фінансової підтримки та стимулювання місцевого самоврядування; упровадження нових підходів до бюджетного процесу, зокрема конщепиіi "new public management".

Ключові слова: бюджетна децентралізація, децентралізація видатків, видатки, видаткові повноваження, місцеве самоврядування. 